\title{
The Effect of Health Officer Role to the Program of Stunting Prevention on First 1000 Days of Life in Indonesia
}

\author{
Ayu Sisca Prastiwi ${ }^{1}$, Al Munawir ${ }^{2}$, Dewi Rokhmah ${ }^{3}$ \\ ${ }^{1}$ Graduate Student, Magister Program of Public Health Education, Jember University, East Java (Indonesia), \\ ${ }^{2}$ Medical Doctor, Philosophy of Doctor, Faculty of Medical Science, Jember University, East Java (Indonesia), \\ ${ }^{3}$ Public Health Lecturer, Faculty of Public Health Education, Jember University, East Java (Indonesia)
}

\begin{abstract}
A role of health officer to prevent stunting rate was very significant, especially on first 1000 days of life. The role of health officer within program of stunting prevention was divided into three parts: basic role, the role on specific nutritional intervention, since the role on nutritional intervention was regarded as sensitive aspect. This research aimed to analyze the effect of implementation from health officer to the program of stunting prevention on the first 1000 days of life, This research was categorized into quantitative research which exerted case control approach, while the data analysis employed bivariate data analysis with logistic regression analysis test. The research sample was taken through cluster random sampling in approximately 275 respondents. The result of data analysis showed the effect of health officer basic role to the stunting prevention. Moreover, the analysis result from those three variables indicated $p$ value $\leq 0,05$, it referred that this variable did not get to be confounding factor in this research and it referred that the significant effect was not existed between health officer role and stunting prevention program on the first 1000 days of life in Indonesia. This result demonstrated that the variable of specific nutrition intervention became the most effective aspect to the program of stunting prevention on the first 1000 day of life, it produced OR value 0.703 (95\% CI: 0.504-0.981). Therefore, the good specific nutrition intervention has the biggest chance as much as 0.703 times in order to prevent stunting rather than the poor specific nutrition intervention.
\end{abstract}

Keywords: Role of Health Officer, Stunting, Basic Role of Health Officer, Specific Nutritional intervention, Sensitive Nutritional intervention.

\section{Introduction}

The incident of stunting is recently the main problem which attacks to the toddlers in almost all parts of world. The impact which is caused by stunting incident was very vital, it not only affects to the toddler health, but is also potential to hamper the national development

\section{Corresponding Author:}

\section{Dr. Al Munawir}

M.Kes., Ph.D., Medical Doctor, Philosophy of Doctor, Faculty of Medical Science, University of Jember, Jawa Timur (Indonesia)

Phone No.: 081559600145

e-mail: almunawir.fk@unej.ac.id and advancement in the future. The bad impacts which are caused by the problem of stunting in short term: disruption of brain development, intelligence, physical growth disorder, and metabolism disorder in the toddler body. Whilst, the bad impacts in long term period from this stunting problem are decline of cognitive skill and learning achievement, decline of immune which causes to the client to easily ill, and the high risk will rise to diabetes, obesity, heart disease and vascular disease, cancer, stroke, and disability on the old age, as well as uncompetitive working quality which results to the low economic productivity. The huge of loss in case of stunting is due to the rise of government expenditure, specifically on the national health insurance ${ }^{(6)}$.

The health officer who is directly involved in the stunting prevalence prevention in Indonesia: Doctor, Nurse, Midwife, Nutrition officer, and Sanitarian. The 
role of health officer as an attempt to realize maximal service in the first stage/primary service on a particular program is very important, since it is considered as a key of health development in Indonesia, thus, the health officer must have duties and responsibilities to run Minimal Service Standard of health sector in order to realize the healthy society in all society and affordable cost efficiency ${ }^{(1)}$. The prevention on stunting incident is focused on the role of health officer as it has been mentioned in the Laws, where the government has also implemented some policies and programs which are nationally executed by the Indonesian Government to the stunting incident. The health development during period of 2015-2019 has been focused on four priority programs, as decrease of death rate on mother and baby, decrease of stunting prevalence, management on transmittable disease and un-transmittable disease. The attempt to rise public nutrition status includes to stunting prevalence is regarded as a priority program of national development which is asserted in the main target of National Development Plans in Medium-term 20152019. The target of decrease on stunting prevalence (either short or very short toddler) in below age of 2 years old is $28 \%$. $^{(7)}$.

\section{Method}

This research was categorized into a quantitative research which employed analytic descriptive research method. This research exerted cluster random sampling as the data collection method. The total research sample were 257 respondents from 13 posyandu. The method of data analysis in this research was univariate analysis by exerting descriptive method, frequency table, while bivariate analysis by exerting logistic regression, which aimed to identify the effect of health officer role to the prevention of stunting. Moreover, the descriptive analysis of this research was employed to illustrate generally about the respondent characteristics who had babies in age of 0-23 months. Meanwhile, the logistic regression analysis was employed to test the effect of independent variable to the prevention of stunting incident.

Research Findings: The respondent characteristic in this research could be categorized into a number of groups: mother's education, mother's occupation, mother's income, and child gender. The detail distribution of respondent characteristic in approximately 275 respondents could be seen on the table 1 below:

Table 1. Distribution of respondent characteristics

\begin{tabular}{|l|c|c|}
\hline Respondent Characteristic & n & $\mathbf{( \% )}$ \\
\hline Educational Background of Mother \\
\hline Unfinished of Elementary School Degree & 21 & 7,6 \\
\hline Elementary School & 73 & 26,5 \\
\hline Junior High school & 56 & 20,4 \\
\hline Senior High School & 80 & 29,1 \\
\hline University & 45 & 16,4 \\
\hline Total & $\mathbf{2 7 5}$ & $\mathbf{1 0 0}$ \\
\hline Occupation of Mother & 159 & 57,8 \\
\hline Employed & 116 & 42,2 \\
\hline Unemployed & $\mathbf{2 7 5}$ & $\mathbf{1 0 0}$ \\
\hline Total & 129 & 46,9 \\
\hline Child Gender & 146 & 53,1 \\
\hline Male & $\mathbf{2 7 5}$ & $\mathbf{1 0 0}$ \\
\hline Female & \multicolumn{2}{|l}{} \\
\hline Total & \multicolumn{2}{|l|}{} \\
\hline
\end{tabular}

Based on the table 1, this research finding indicated that the majority of respondents were graduation of Senior High School Degree 80 respondents $(29,1 \%)$, employed category 159 respondents $(57,8 \%)$, having income more than UMK standard 179 respondents $(65,1 \%)$, and child of female gender 146 respondents $(53,1 \%)$.

Cross Tabulation on role of health officer and stunting on Toddlers. The total of respondents in 13 posyandu were 275 respondents. The result of this cross tabulation was to determine five evaluation categories, this was acquired from accumulation of all questionnaires from each indicator in a variable of basic role, and the result of cross tabulation on basic role effect of health officer to the program of stunting prevention could be seen on the table 2 below: 
Table 2. Frequency distribution which was based on the role of health officer

\begin{tabular}{|c|l|c|c|c|c|c|c|}
\hline \multirow{2}{*}{ No } & \multirow{2}{*}{ Category } & \multicolumn{2}{|c|}{ Basic Role } & \multicolumn{2}{c|}{ Specific Nutritional intervention } & \multicolumn{2}{c|}{ Sensitive Nutritional intervention } \\
\cline { 2 - 7 } & & $\mathbf{n}$ & $\mathbf{( \% )}$ & $\mathbf{n}$ & $\mathbf{( \% )}$ & $\mathbf{n}$ & $\mathbf{( \% )}$ \\
\hline 1. & Very Good & 3 & 1,1 & 0 & 0 & 13 & 4,7 \\
\hline 2. & Good & 142 & 51,6 & 122 & 44,4 & 137 & 49,8 \\
\hline 3. & Quite Good & 62 & 22,5 & 85 & 30,9 & 86 & 31,3 \\
\hline 4. & Not Good & 68 & 24,7 & 68 & 24,7 & 39 & 14,2 \\
\hline 5. & Not Very Good & 0 & 0 & 0 & 0 & 0 & 0 \\
\hline & Total & $\mathbf{2 7 5}$ & $\mathbf{1 0 0}$ & $\mathbf{2 7 5}$ & $\mathbf{1 0 0}$ & $\mathbf{2 7 5}$ & $\mathbf{1 0 0}$ \\
\hline
\end{tabular}

Based on the table 2, this research finding referred that the basic role of Health Human Resource in the attempt of stunting prevention was mainly good in approximately 142 (51,6\%). The indicators which were used to arrange the basic role of Health Human Resource: communicator, motivator, facilitator, counselor. The role of specific nutritional intervention as an attempt to prevent stunting was mostly good in approximately 122 $(44,4 \%)$. The indicators which were used to establish the role of specific nutritional intervention: Pregnancy record of mother which was influenced by the role of health officer and the role of health officer intervention on the toddler in age range $0-23$ months. The role of sensitive nutritional intervention as an attempt to prevent stunting incident was mainly good in approximately 137 $(49,8 \%)$. The indicators which were used to arrange the role of sensitive nutritional intervention covered to the role of clean water provision and sanitation, program of Keluarga Berencana, health insurance, basic childbirth assurance, and nutrient education.

The result of conformity model test from analysis of health officer role effect to the stunting prevention program on the first 1000 days was shown on the table 3 below:

Table 3. Analysis between independent variables and stunting

\begin{tabular}{|c|c|c|c|c|}
\hline \multirow{2}{*}{ Variable } & \multirow{2}{*}{$P$ value } & \multirow{2}{*}{$\operatorname{Exp}(B)$} & \multicolumn{2}{|c|}{$95 \% \mathrm{CI}$} \\
\hline & & & Lower & Upper \\
\hline Basic role of Health Human Resource & 0.000 & 0.431 & 0.305 & 0.609 \\
\hline Specific nutritional intervention & 0.038 & 0.703 & 0.504 & 0.981 \\
\hline Sensitive nutritional intervention & 0.002 & 0.575 & 0.402 & 0.822 \\
\hline
\end{tabular}

The table 3 illustrated the analysis result from those three variables which showed p-value $>0,05$, which referred that the variable was not a confounding factor in this research. Besides, this result indicated that the variable of specific nutritional intervention was a factor with the greatest risk which was related to the stunting incident prevention, since it delivered to the biggest Odds Ratio value 0.703 (95\% CI: 0.504-0.981). Thus, the respondents who have received good specific nutritional intervention would have more chance 0.703 times to prevent stunting incident, if it was compared to the bad specific nutritional intervention.

\section{Discussion}

The basic role was covered to the role as communicator, facilitator, counselor, and also motivator . The basic role of health officer in stunting prevention was in line with this following theory, where the role as a communicator must be owned by all health officers. The health officer as a communicator must be able to deliver information, educate and teach individual, family, group and society, and other health officers according to their responsibilities ${ }^{(1)}$. Further, the health officer as an educator must educate or conduct health counseling 
to the clients and was completed by an evaluation which aimed to develop health learning ${ }^{(18)}$. The role of health officer as a motivator was also important as other roles. The health officer must be able to give motivation, direction, guidance, and increase awareness on the client ${ }^{(5)}$. The characteristics of health officer as a motivator were to provide assistance, bring client awareness, and encourage group to recognize potential and problem, and be able to develop the potential in order to solve the problem ${ }^{(7)}$. The role of facilitator must be also owned by every health officer within health promotion. As a facilitator, the health officer must be able to give technical guidance and empower the client to develop to the expected goal achievement. The facilitator must be skilful to integrated three important aspects, as optimization of facilities, time provision, and optimization of society participation ${ }^{(2)}$. The role of health officer as a counselor in aspect of health socialization or promotion was very needed, the health officer must be able to give approaches and trainings to the local public figure, help client to understand information take decision relating to the medical treatment, and facilitate the client and family as well as all society to improve optimal health situation ${ }^{(13)}$.

The role of health officer as an attempt of specific nutrition intervention was the direct role or involvement which given on $0-23$ months $^{(6)}$. It was indicated the effect of food intake which covered to energy intake protein intake, fat intake, carbohydrate intake, calcium intake, zinc intake to the stunting incident on toddler in the age range $6-35$ months ${ }^{(8)}$. The toddler age should be introduced to many kinds of food, it was not only to give education relating to kind of food, but also to fulfill the nutritional need in order to help the process of growth ${ }^{(10)}$.. The toddler who received non-exclusive breast milk have risk of stunting 16.5 greater than the toddler who received exclusive breast milk ${ }^{(6)}$. The role of Health Officer to give education which related to smoking habit was also crucial, it was in line with the theory from the center of social insurance of University of Indonesia, where the research finding had showed that the cigarette consumption on parent would affect to stunting children ${ }^{(10)}$. The smoking behavior on parent was estimated to influence the stunting children through two ways. First, through the cigarette smoke which was able to disturb nutrient absorption on children, second, aspect of cigarette buying cost which would affect the parent to reduce the nutritious food cost, health cost, education cost, etc ${ }^{(12)}$.
The role of health officer as an attempt of sensitive nutrition intervention was done by multi-sector. Furthermore, the role of health officer as an attempt of sensitive nutrition intervention has shown a good role result. The effect of health officer role on sensitive nutritional intervention to the stunting prevention program in the first 1000 days of life was an attempt to prevent and decrease nutritional problems indirectly ${ }^{(6)}$. Many studied have analyzed the access relation between clean water and stunting incident. Besides malnutrition, the bad water condition and sanitation would also affect to the high rate of stunting incident on children in Indonesia. The ground floor and sanitation could improve the stunting incident, since the children who lived in the house with ground floor and bad sanitation were tended to suffer illness, this condition was a leading factor of stunting ${ }^{(11)}$. The role of health officer was directed to prevention attempt, because the sanitation and clean water was regarded as a cross sectoral activity which involved the other role of housing ministry and irrigation sector in general ${ }^{(15)}$. The effect of Keluarga Berencana program was aimed to prevent stunting incident and was considered as an attempt of government in the stunting prevention program through National Population and Family Planning Board (BKKBN) ${ }^{(19)}$. The woman who have good access to the health service was who have received information regarding to that service from health officer as doctor, midwife, or nurse. For the society in low level of economic status, the cost limitation was often the biggest factor which hampered the woman access to the health service, especially the safe childbirth ${ }^{(14)}$. The effect of health officer role to the nutritional improvement of societyhas been employed in multisectoral, through socialization from the government and non-government regarding to the importance of nutritional intake on pregnant mother ${ }^{(17)}$

\section{Conclusion}

Prevalence of stunting which was based on this research, indicated that the number was still high in approximately $36.7 \%$, it was valued as high level according to WHO standard, since it was above $20 \%$. The effect between basic role of Health Officer, the effect of Health Officer role, the effect of Health Officer role and stunting incident.

Conflict of Interest: None

Source of Funding: Self

Ethical Clearance: This research has undergone 
ethical test in ethics commission of health research of Faculty of Dentistry, University of Jember in this following registration number 632/UN25.8/KEPK/ DL/2019.

\section{References}

1. Potter A, Perry AG. Fundamental of Nursing. In:Ratna Komalasari, et al, editors. Buku ajar fundamental keperawatan: konsep, proses, dan praktik, edisi 4, volume 2. Jakarta: EGC; 2007. p.66-80.

2. Adistie F, Lumbantobing VBM, Maryam, NNA. Pemberdayaan Kader Kesehatan Dalam Deteksi Dini Stunting Dan Stimulasi Tumbuh Kembang Pada Balita. Jurnal MKK. 2018;1(2): 173-184. https://doi.org/10.24198/mkk.v1i2.18863

3. Aryastami, Ni Ketut, Ingan T. Kajian Kebijakan Dan Penanggulangan Masalah Gizi Stunting Di Indonesia. Buletin Penelitian Kesehatan. 2017;45 (4): 233-240. https://doi.org/10.22435/bpk. v45i4.7465.233-240

4. Damayanti RA., Lailatul M, Farapti. Perbedaan Tingkat Kecukupan Zat Gizi Dan Riwayat Pemberian Asi Ekslusif Pada Balita Stunting Dan Non Stunting. Jurnal Media Gizi Indonesia. 2016;11(2):61-69. http://doi.org/10.20473/mgi. v11i1.61-69

5. Katoch OR dan Sharma A. Socioeconomic Factors, Living Conditions and Child Undernutrition among School going Children in Rural Areas of district Doda, Jammu \& Kashmir, India: A Preliminary Stud. Indian J Nutri. 2016;3(1):123. https://doi. org/10.5958/2249-7315.2017.00375.6

6. Kemenkes. Situasi Balita Pendek di Indonesia[Internet]. Buletin Jendela Data dan Informasi Kesehatan. 2018 [cited 17 Oktober 2018]. Available from: www.kemkes.go.id/download/ bulletin/Buletin-Stunting-2018

7. Nasional KPP. Rencana Program Jangka Menengah (RPJM) 2015-2019. Jakarta: PP Nomor 2 Tahun 2015;2015.

8. Nikmatul. Analisis Determinan Kejadian Stunting Pada Balita (Studi di Wilayah Kerja Puskesmas Sumberjambe, Puskesmas Kasiyan dan Puskesmas Sumberbaru Kabupaten Jember) . Health Nation. 2018:2 (1). http://repository.unej.ac.id/ handle/123456789/85863

9. Novita N, Fransisca. Promosi Kesehatan dalam
Pelayanan Kebidanan. Jakarta: Salemba Medika; 2011. P.27.

10. Purwaningrum S,Yuniar W. Hubungan antara Asupan Makanan dan Status Kesadaran Gizi Keluarga dengan Status Gizi Balita di Wilayah Kerja Puskesmas Sewon I Bantul. Jurnal Kesehatan Masyarakat. 2012; 6(3):190-202. http://doi. org/10.12928/kesmas.v6i3.1054

11. Renyoet,S., Brigette, Drajat M, Dadang S. 2015. Potensi Kerugian Ekonomi Karena Stunting Pada Balita di Indonesia Tahun 2013. J. Gizi Pangan,.2016:11 (3);247-254. http://journal.ipb. ac.id/index.php/jgizipangan/article/view/16461

12. Rodiah S., Lusiana E. dan Agustine $M$. Pemberdayaan Kader Pkk Dalam Usaha Penyebarluasan Informasi Kesehatan Jatinangor. Jurnal Dharmakarya. 2016; 5(1). https://doi. org/10.24198/dharmakarya.v5i1.9923

13. Setiawan SA. Hubungan Peran Perawat dengan Lama Kesembuhan Pasien di Ruang Paru RSU Fatmawati Semarang. Tesis. Semarang: Undip; 2010.

14. Simbolon D. Pengaruh Kepemilikan Jaminan Kesehatan Masyarakat Miskin Terhadap Status Kelahiran Dan Kejadian Stunting Pada Baduta Indonesia. Jurnal Kebijakan Kesehatan Indonesia. 2014;03(2):55-65. https://doi.org/10.22146/ jkki.36359

15. SilveiraKBR, et al. Association between malnutrition in children living in favelas, maternal nutritional status, and environmental factors. Journal the pediatric. 2018; 84(4): 551-562. https:// doi.org/10.29024/aogh.2361

16. Sulistyawati A. Faktor-Faktor Yang Berhubungan Dengan Kejadian Stunting Pada Balita. Jurnal Ilmu Kebidanan. 2019; 5(1): 21-30. https://www. researchgate.net/publication/331088268

17. Sumarmi SM. Peran Sarjana Kesehatan Masyarakat Dalam Gerakan Penyelamatan 1000 Hari Pertama Kehidupan Untuk Menurunkan Stunting Dan Angka Kematian Ibu. Surabaya: Departemen Gizi Kesehatan - FKM Universitas Airlangga. 2015.

18. Suryahadi A, Febriany V, Yumna A. Expanding Social Security In Indonesia: The Current Processes And Challenges [Internet]. Working papers[cited 17 Oktober 2018]. Available from: https://media. neliti.com/media/publications/639

19. Tentama F., Lestari, Wicaksono E .Penguatan 
Keluarga Sebagai Upaya Menekan Angka Stunting Dalam Program Kependudukan, Keluarga Berencana Dan Pembangunan Keluarga (KKBPK). Jurnal Pemberdayaan: Publikasi Hasil Pengabdian kepada Masyarakat. 2018;2(1):113-120. https:// doi.org/10.12928/jp.v2i1.546
20. Vilcins, D., Sly, P. D. and Jagals, P. Environmental Risk Factors Associated with Child Stunting: A Systematic Review of the Literature. Annals of Global Health. 2015; 84(4): 551. http://doi. org/10.29024/aogh.2361 